\title{
Integrated sustainable anaerobic treatment for low strength wastewater
}

\author{
S. I. Abou-Elela ${ }^{1}$, M. E. Fawzy ${ }^{1}$, M. El-Khateeb ${ }^{1}$ \\ \& W. Abdel-Halim ${ }^{2}$ \\ ${ }^{I}$ Water Pollution Research Department, National Research Center, \\ Cairo, Egypt \\ ${ }^{2}$ Housing and Building National Research Center, Cairo, Egypt
}

\begin{abstract}
The main objective of this study is to demonstrate and implement a cost effective system for low strength municipal wastewater treatment in rural areas. An integrated compact anaerobic treatment pilot plant unit was designed, constructed and operated for almost two years. The pilot plant consists of three successive compartments mainly; primary sedimentation (PS), packed bed up flow anaerobic sludge blanket (P-UASB) and inclined plate settler (IPS). The pilot plant was operated continuously at a hydraulic loading rate of $6 \mathrm{~m}^{3} /$ day, average organic loading rate of $2.5 \mathrm{~kg} \mathrm{COD} / \mathrm{m}^{3} /$ day and average retention time of $4 \mathrm{hrs}$ at the P-UASB and a total retention time $6 \mathrm{hrs}$ for the integrated treatment unit. The performance of the treatment train was monitored via physico-chemical as well as bacteriological and parasitological analysis. The average removal rates of chemical oxygen demand (COD), biological oxygen demand $\left(\mathrm{BOD}_{5}\right)$ and total suspended solids (TSS) were $78 \%, 79 \%$ and $91 \%$, respectively with corresponding average residual values of $71 \mathrm{mgO}_{2} / 1,39 \mathrm{mgO}_{2} / 1$ and $18 \mathrm{mg} / \mathrm{l}$. Pathogenic analysis indicated that great majorities were removed but still some residuals exist. The treated wastewater, after disinfection, was complying with the Egyptian Code for wastewater reuse in restricted irrigation. The results indicated that the total life cost of the pilot plant, during the research period, proved to be a cost-effective process for treating low strength wastewater.
\end{abstract}

Keywords: low strength wastewater, anaerobic treatment, packed upflow anaerobic sludge blanket, inclined plate settler. 


\section{Introduction}

Wastewater is one of the challenging environmental problems in Egypt. Wastewater treatment in rural areas and small communities lags far behind potable water supply; this practice causes serious environmental and hygienic problems. The high construction, operation and maintenance costs for a centralized conventional wastewater collection and treatment system represent an obstacle for the Egyptian government in the installation of such a system in rural areas. All that made the on-site low cost options or decentralized sanitation systems are all become interesting solution for application and testing [1]. This alternative can meet a sustainable wastewater management requirement and has a promising future, especially for developing countries [2]. From the perspective, one technology that could deliver similar effluent quality compared to the centralized conventional wastewater treatment is the anaerobic technology [3].

Nowadays, intensive research works have been conducted on the treatment of dilute sewage wastewater at ambient temperatures using anaerobic reactors such as upflow anaerobic sludge blanket (UASB), expanded granular bed (EGSB) and anaerobic baffled reactors (ABR). Feng et al. [4] studied the performance of bamboo carrier anaerobic baffled reactor for treatment of dilute domestic sewage from rural areas of china, TCOD removal efficiency varied from $79 \%$ at $48 \mathrm{hrs}$ HRT to $69 \%$ at $18 \mathrm{hrs}$ HRT. Manariotis and Grigoropoulos [5] conducted experiments on anaerobic baffled reactor to evaluate the treatment of low strength synthetic wastewater (COD of 300-400 $\mathrm{mgO}_{2} / \mathrm{l}$ ) at $26^{\circ} \mathrm{C}$ and HRTs of 24 and $12 \mathrm{hrs}$ and observed that COD removal efficiencies ranged from $87 \%$ to 91\%. Sabry [6] used upflow septic tank / Baffled reactor system which produced an average removal values of COD, BOD and TSS of $84 \%, 81 \%$ and $89 \%$, respectively at a retention time of $20 \mathrm{hrs}$. Also, Gopala et al. [7] studied the performance of $10 \mathrm{~L}$ laboratory scale $\mathrm{ABR}$ operated for almost 600 days at a temperature ranging from $20^{\circ} \mathrm{C}$ to $32^{\circ} \mathrm{C}$ for treating low strength complex wastewater of COD $500 \mathrm{mgO}_{2} / 1$ at HRTs of 20,15,10,8,6 hrs with corresponding organic rates of $0.8,1.2,1.5$ and $2 \mathrm{kgCOD} / \mathrm{m}^{3} /$ day. The removal efficiencies of COD and BOD exceeded $88 \%$. Furthermore, the use of packing material in upflow anaerobic sludge blanket plays an important role in increasing the surface area for faster biofilm development and improved methanogenesis. Many carrier materials have been investigated regarding their stability as support for biofilm, including cheap, readily available materials like, sand, clay, glass, quartz and a number of plastics [8]. Picanco et al. [9] reported that the efficiency of removing organic matters in fixed-bed reactors is directly related to the characteristics of the support material used for immobilization of anaerobes. It is widely accepted that organic support material has a higher affinity than inorganic material [10]. It is worth noting that most of the studies using anaerobic reactors for low strength wastewater were carried out at high retention times and with or without packing materials. Therefore, the main objective of this study is to investigate and evaluate the performance and capability of a compact anaerobic packed bed reactor with lamella, operated at a very low retention time (4 hrs), for sustainable treatment and reuse in agricultural purposes. 


\section{Material and methods}

\subsection{Description of the pilot plant}

The integrated combined anaerobic treatment unit consists of three successive compartments namely; primary sedimentation (option), up flow anaerobic sludge blanket packed with lamella sheets (P-UASB) and inclined plate settler. The unit is located at a nearby wastewater treatment plant. The pilot plant unit is made of PVC of $8 \mathrm{~mm}$ thickness. The packing material is a lamella corrugated plastic sheets (Figure 1) with a specific surface area of $150 \mathrm{~m}^{2} / \mathrm{m}^{3}$. The treatment train and the schematic diagram of the pilot unit are shown in Figures 2 and 3. A full description of the treatment unit is given in Table 1 .

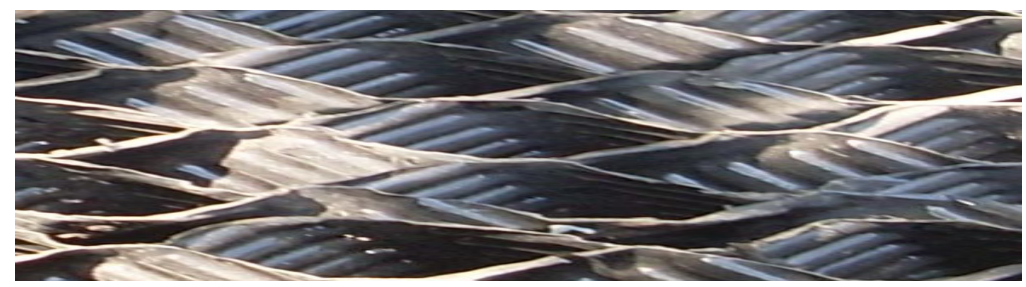

Figure 1: $\quad$ Photo for the packing material (lamella sheets).

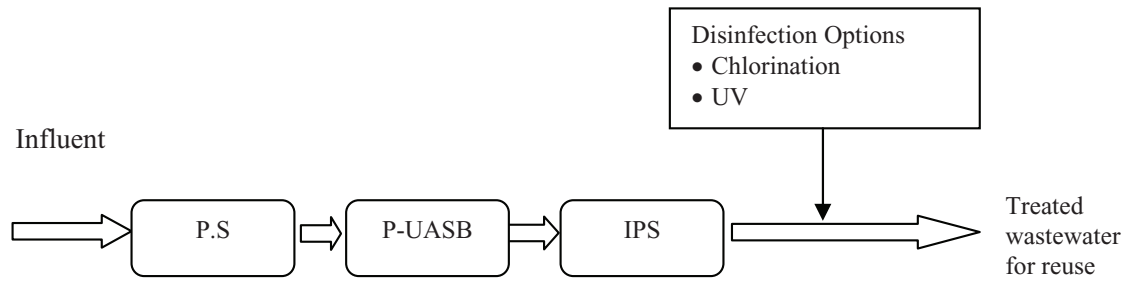

Figure 2: $\quad$ Schematic diagram of the pilot plant.

\subsection{Operating conditions}

The pilot plant was operated continuously for almost two years at a hydraulic loading rate of 6.0-6.5 m 3 day, average organic loading rate of $2.5 \mathrm{~kg}$ $\mathrm{COD} / \mathrm{m}^{3} /$ day and at ambient temperature ranged from $17^{\circ} \mathrm{C}$ to $35^{\circ} \mathrm{C}$ for almost 2 years. The system was fed with domestic sewage after coarse screening to prevent clogging and damage caused by rough suspended solids of influent wastewater. During the start -up period the flow rate was gradually increased from $2.0 \mathrm{~m}^{3} /$ day up to $6.0 \mathrm{~m}^{3} /$ day until it reached the steady state conditions. 

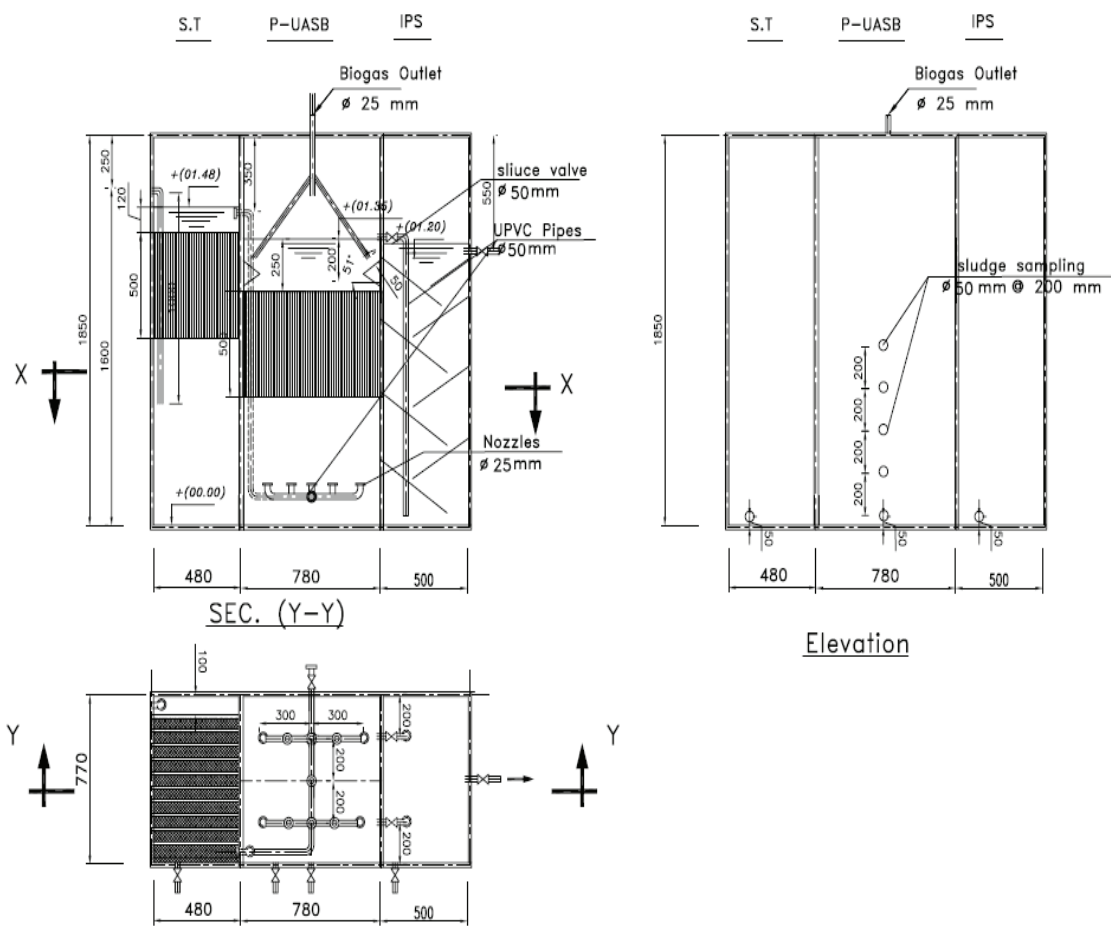

Elevation

SEC. $(X-X)$

Figure 3: $\quad$ Engineering design of the pilot plant.

Table 1: $\quad$ Full description of the treatment unit.

\begin{tabular}{|c|c|c|c|}
\hline Parameters & P.S & P-UASB & IPS \\
\hline $\begin{array}{l}\text { Designed Retention Time } \\
\text { (RT) (Hrs) }\end{array}$ & $0.5-1 \mathrm{hrs}$ & $4 \mathrm{hrs}$ & $1 \mathrm{hr}$ \\
\hline Sizing (liter) & 250 & 1080 & 250 \\
\hline Flow rate $\left(\mathrm{m}^{3} /\right.$ day $)$ & 1 & 4.32 & 1 \\
\hline Upflow velocity $(\mathrm{m} / \mathrm{h})$ & - & 0.42 & - \\
\hline Remarks & $\begin{array}{l}\text { Option if } \\
\text { needed }\end{array}$ & $\begin{array}{l}\text { Packing material is } \\
\text { corrugated plastic } \\
\text { sheets with specific } \\
\text { surface area Ca. } 150 \\
\mathrm{~m}^{2} / \mathrm{m}^{3}\end{array}$ & $\begin{array}{l}\text { Provide by } \\
\text { plastic } \\
\text { inclined } \\
\text { sheets }\left(60^{\circ}\right. \\
\text { inclination) }\end{array}$ \\
\hline
\end{tabular}




\subsection{Acclimatization and sludge inoculation}

The acclimatization period of the treatment unit took about 4 months from the first inoculation to the P-UASB reactor. It was seeded with primary digested sludge obtained from a secondary wastewater treatment plant. The sludge was kept in anaerobic condition before feeding to the P-UASB. The seeded sludge has a concentration of $63.4 \mathrm{~g} / 1$ for TSS and $27.3 \mathrm{~g} / \mathrm{l}$ for VSS. The volume of the sludge represents almost $40 \%$ from the total volume of the P-UASB reactor. During the steady state operation phase, the excess sludge was discharged every two months. Before sludge withdrawal, several sludge samples were collected from the different points along the reactor height at 10,28,41,54 and $69 \mathrm{~cm}$ from the reactor bottom. These samples were analyzed for total solids (TS) and Volatile solids (VS). Accordingly, the composite sludge concentration inside the reactor was calculated and compared to that of the start initial value of the seeded sludge as a potential to determine the excess sludge concentration. In each wasting case, the volume of the excess sludge was observed. Furthermore, the performance of the integrated anaerobic treatment unit was monitored by intermittent measurements of COD and TSS until it reached the steady state.

\subsection{Analysis}

The investigated physicochemical analysis were $\mathrm{pH}$, temperature, turbidity, total chemical oxygen demand (TCOD), soluble chemical oxygen demand (SCOD), Biological oxygen demand $\left(\mathrm{BOD}_{5}\right)$, total suspended solids (TSS), volatile suspended solids (VSS) ; total kjeldahl nitrogen (TKN), ammonia $\left(\mathrm{NH}_{3}\right)$, total phosphorous (TP), oil and grease \& all extractable matters by chloroform, hydrogen sulphide and volatile fatty acids (VFA). The gas produced was detected using portable ambient air analyzer (MIRAN SapphlRe, 205A series), while its flow was measured using gas flow meter. The pathogenic analysis include fecal coliform (FC) and helminthes (Nematodes, cestodes and trematodes). All the analysis, unless otherwise specified, were carried out according to the American Public Health Association for Examination of Water and Wastewater [11].

\section{Results and discussion}

\subsection{Start up of the Pilot Plant Treatment Unit}

To reach the steady-state conditions, the system was operated at $2.88 \mathrm{~m}^{3} /$ day then gradually increased to $4.33 \mathrm{~m}^{3} /$ day, then to $6.0 \mathrm{~m}^{3} /$ day. The system reached the steady state after almost four months as indicated by constant measurements of total COD and turbidity which reached $158 \mathrm{mgO}_{2} / 1$ and $70 \mathrm{NTU}$, respectively.

\subsection{Wastewater characterization}

From the results depicted in Table 2 and Figure 4, it is obvious that the wastewater fed to the treatment unit is classified as a low strength wastewater 
Table 2: $\quad$ Physico-chemical characterization of raw wastewater.

\begin{tabular}{|c|c|c|c|c|}
\hline Parameters & Unit & Min. & Max. & Average* \\
\hline pH-value & -- & 6.78 & 7.54 & -- \\
\hline Turbidity & NTU & 89 & 208 & 135.5 \\
\hline $\mathrm{COD}_{\text {tot }}$ & $\mathrm{mg} \mathrm{O}_{2} / 1$ & 292 & 398 & 320.5 \\
\hline $\mathrm{COD}_{\mathrm{sol}}$ & $\mathrm{mg} \mathrm{O}_{2} / \mathrm{l}$ & 77 & 180 & 108 \\
\hline $\mathrm{COD}_{\text {part }}$ & $\mathrm{mg} \mathrm{O}_{2} / 1$ & 215 & 218 & 211.6 \\
\hline $\mathrm{BOD}_{5 \text { tot }}$ & $\mathrm{mg} \mathrm{O}_{2} / 1$ & 140 & 240 & 190.8 \\
\hline \begin{tabular}{ll} 
Settleable & \multicolumn{1}{c}{$10 \mathrm{~min}$} \\
Solids & \\
30min
\end{tabular} & $\mathrm{ml} / \mathrm{l}$ & $\begin{array}{l}0.5 \\
0.8\end{array}$ & $\begin{array}{l}2.5 \\
3.0\end{array}$ & $\begin{array}{c}1.38 \\
1.7\end{array}$ \\
\hline TSS & $\mathrm{mg} / \mathrm{l}$ & 110 & 289 & 200 \\
\hline VSS & $\mathrm{mg} / \mathrm{l}$ & 94 & 243 & 150.9 \\
\hline TKN & $\mathrm{mgN} / 1$ & 24.9 & 66.8 & 40.0 \\
\hline $\mathrm{NH}_{4}-\mathrm{N}$ & $\mathrm{mgN} / \mathrm{l}$ & 14.0 & 30.0 & 22.6 \\
\hline T.P & $\mathrm{mg} / \mathrm{l}$ & 2.8 & 6.6 & 3.8 \\
\hline Oil \& grease & $\mathrm{mg} / \mathrm{l}$ & 23.4 & 88.0 & 46.1 \\
\hline $\mathrm{H}_{2} \mathrm{~S}$ & $\mathrm{mg} / \mathrm{l}$ & 1.8 & 9.5 & 5.0 \\
\hline
\end{tabular}

*Average of 25 samples.

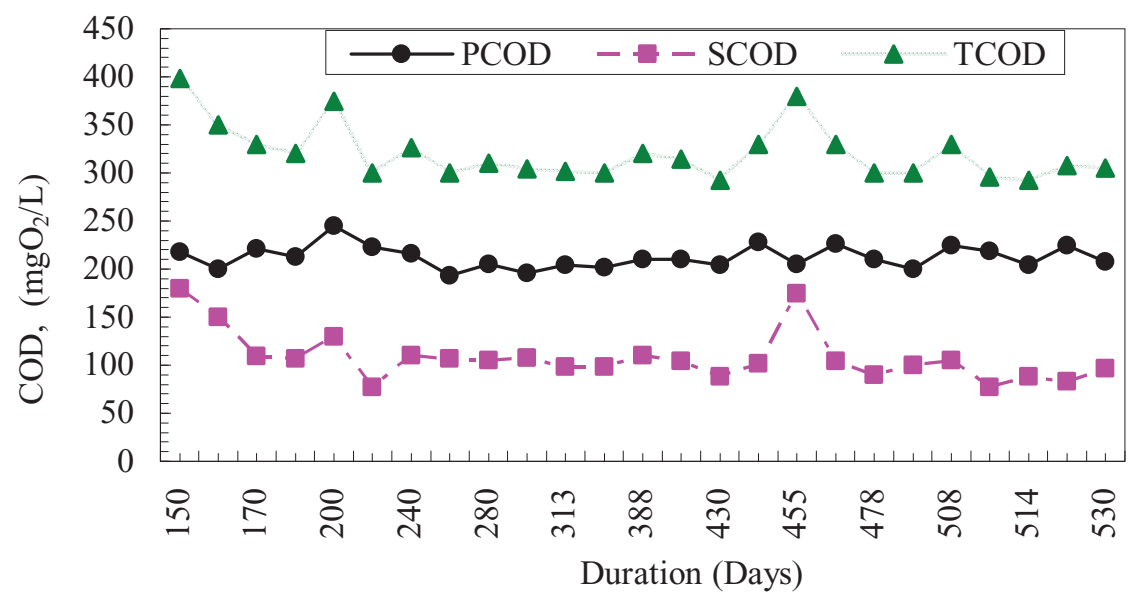

Figure 4: $\quad$ COD fractions for raw wastewater.

[12]. The average values for total COD, soluble COD and particulate COD were $320.5 \mathrm{mgO}_{2} / 1,108 \mathrm{mgO}_{2} / 1,211.5 \mathrm{mgO}_{2} / 1$, respectively. The average BOD and total suspended solids were $190 \mathrm{mgO}_{2} / 1$ and $200 \mathrm{mg} / \mathrm{l}$, respectively. 


\subsection{Performance of the integrated anaerobic treatment unit}

\subsubsection{COD fractions, BOD and TSS removal}

The overall efficiency of the integrated anaerobic treatment unit is shown in Figure 5. The average removal rates of TCOD, BOD and TSS were 78\%, 79\% and $91 \%$, respectively with corresponding residual values of $71 \mathrm{mgO}_{2} / 1,39.7$ $\mathrm{mgO}_{2} / \mathrm{l}$ and $18 \mathrm{mg} / \mathrm{l}$. It is obvious from the values depicted in the figure that the use of packing material in the UASB, with high surface area, aids in the accumulation of suspended solids at the bottom of the reactor so increasing the average removal efficiency of TSS to $62 \%$. Also, it was found that the use of inclined plate settler, which is provided by plastic inclined sheets at $60^{\circ}$ inclination, improves the settliability of suspended solids (up to $91 \%$ removal of TSS) which is then accumulated and discharged with the sludge. Also, it can be explained that suspended solids settle, agglomerate and flow down the sloped plate surfaces, while the treated effluent is conducted upwards. Moreover, a biofilm is developed on the surface of IPS where biocatalysts such as microorganisms, particulate matters and extracellular polymers exist on the surface of an inert media or adhere with other microorganisms [13]. Similar results were obtained [14]. They found that clean vertical sheets of reticular polyurethane foam (RPF) could effectively remove suspended solids from domestic sewage mainly because of their high specific surface area and porosity; moreover the presence of a biofilm improved the bisorption of suspended and colloidal particles. Although the discharge of the accumulated sludge from the system reduce the total amount of biomass in the reactor but it prevents clogging of the filter media. The results in Figure 5 also show that the TCOD improved by $53.4 \%$ in the IPS compared to P-UASB, while the SCOD was limited to

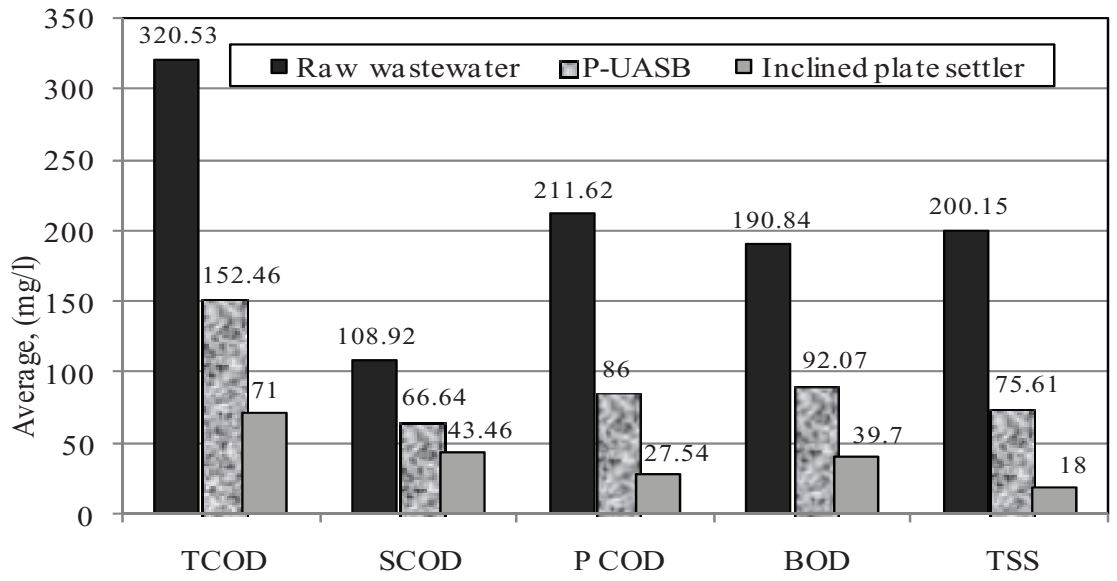

Figure 5: $\quad$ Efficiency of the treatment system. 
$60 \%$. This may be explained that SCOD (partly) consisted of soluble microbial products (SMP) which are resistant to anaerobic degradation. These are in agreement with [15].

\subsubsection{VFA removal}

The average VFA concentration in the P-UASB increased from $35.6 \mathrm{mg} / \mathrm{l}$ in the influent wastewater to $73.2 \mathrm{mg} / \mathrm{l}$ and consequently slightly lowered the $\mathrm{pH}$ value from 7.2 to 6.9. This demonstrates that hydrolysis and acidogenesis were the main biochemical activities taking place in the P-UASB [16]. However, degradation of VFA took place in the final effluent and it was reduced to $28.7 \mathrm{mg} / \mathrm{l}$ resulting in the increase of the $\mathrm{pH}$ value of the final effluent to 7.14. This indicated that the organic content in wastewater such as COD and VFA are consumed by the biofilm passing through the reactor P-UASB and IPS.

\subsubsection{Nutrient removal}

The integrated anaerobic treatment unit displayed nutrient removal efficiency of $68.5 \%$ for total organic nitrogen, $66.8 \%$ for ammonia and $65 \%$ for total phosphorous at a HRT in P-UASB of $4 \mathrm{hrs}$. These results are close to that obtained by [17], although they used multi stage treatment unit (UASB - down flow hanging sponge) at a total HRT of $10.7 \mathrm{hrs}$.

\subsubsection{Sludge bioactivity}

Figure 6 show the sludge sampling including the average sludge concentrations along different height levels of the reactor. This figure shows the initial concentration of the sludge when it was measured in the laboratory without any expansion $(\mathrm{TS}=84.4 \mathrm{~g} / \mathrm{L}$; VS $=38.9 \mathrm{~g} / \mathrm{L})$. The initial concentration after expansion (sludge blanket at $10 \mathrm{~cm}$ above reactor's bottom) due to the up-flow inside the reactor was $(\mathrm{TS}=63.4 \mathrm{~g} / \mathrm{L} ; \mathrm{VS}=27.3 \mathrm{~g} / \mathrm{L})$. Although this reduction in the biomass concentration of the sludge, the reactor still working with acceptable performance and sludge activity. The sludge methanogenic activity was determined along the operation time at different temperature ranges and compared to the actual sludge loading rate according to the fluctuated concentrations of the influent wastewater. It was found that the sludge loading rates were fluctuated within range of $0.13-0.17 \mathrm{~g} \mathrm{COD} / \mathrm{g}$ VS.d with an average value of $0.15 \mathrm{~g} \mathrm{COD} / \mathrm{g}$ VS.d along the different experimental runs and temperatures. The average values of total methanogenic sludge bio-activity were $0.11 \mathrm{~g} \mathrm{COD}_{\text {rem }} / \mathrm{g}$ VS.d along the different experimental runs. This means that the sludge has a very good response and interaction with the increasing of sludge loading rate without any risk of overloading inhibition. It is also confirmed the ability of sludge activity to overcome the obstructions due to change of operating conditions.

\subsubsection{Biogas production}

The quantity and quality of biogas produced were measured frequently. The methane content was ranged between $72 \%$ and $77 \%$ of the total biogas. Also, the biogas included some other gases such as nitrogen, $\mathrm{NH}_{3}, \mathrm{CO}_{2}, \mathrm{CO}$ and $\mathrm{N}_{2} \mathrm{O}$. The specific methane gas production was determined according to the removed COD 
and influent COD as well as the influent wastewater discharge. The removed COD-specific $\mathrm{CH}_{4}$-gas production was ranged between $180-220 \mathrm{~L} \mathrm{CH}_{4} / \mathrm{kg}$ $\mathrm{COD}_{\text {removed }}$ with an average value $200 \mathrm{~L} \mathrm{CH}_{4} / \mathrm{kg} \mathrm{COD}$ removed. The influent CODspecific $\mathrm{CH}_{4}$-gas production was ranged between $80-160 \mathrm{~L} / \mathrm{kg} \mathrm{COD}_{\text {in }}$ with an average value of $120 \mathrm{~L} / \mathrm{kg} \mathrm{COD}$ in along the whole runs. In comparison to the previous studies, it is proved that the obtained values are considered in a normal range of methane production for anaerobic treatment of municipal wastewater $[13,18]$.

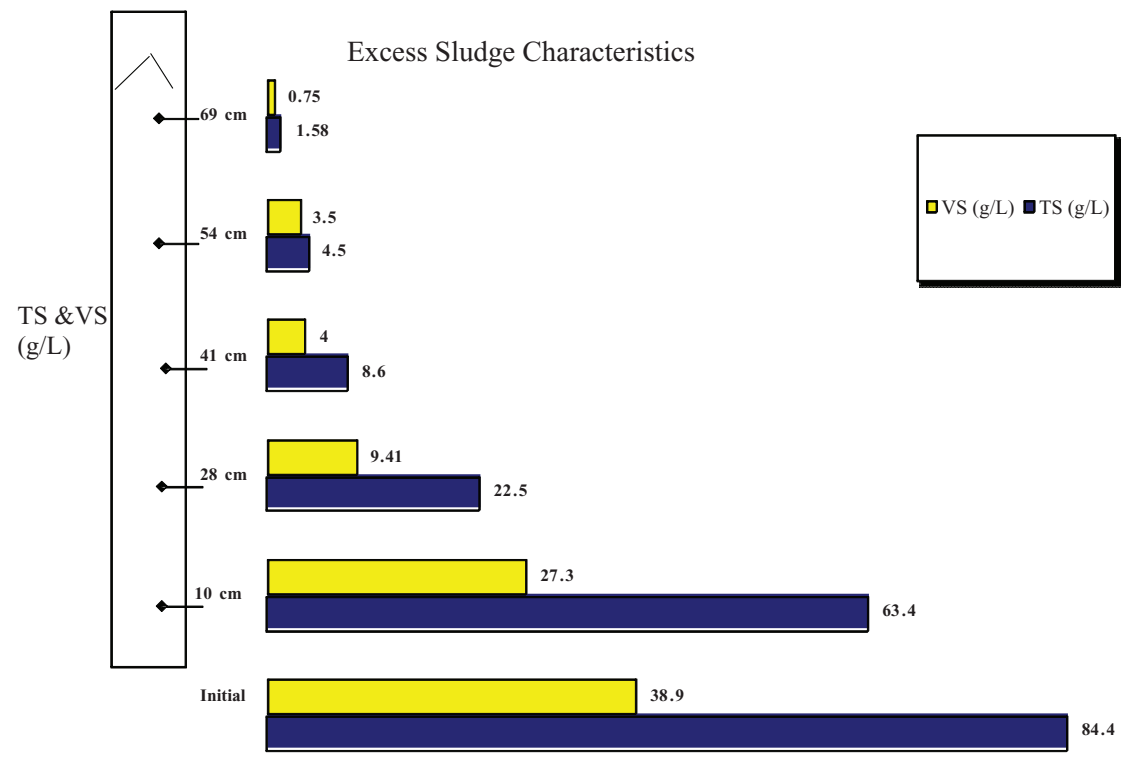

Withdraw levels from the bottom of UASB

Figure 6: $\quad$ Sludge concentration in the P-UASB reactor.

\subsubsection{Pathogens removal}

The results shown in Table 4 indicated that the average removal rate of fecal coliform reached $99.92 \%$ with average residual value of $8.2 \times 10^{2}$. Also, total helminthes (nematodes, cestodes and trematodes) could not be completely removed due to the short HRT and the high upflow velocity in the P-UASB. The mean values of nematodes, cestodes and trematodes indicated that the total helminthes reached 0.3 ova / liter. Feng et al [4] reported that anaerobic process had certain effect on the removal of pathogenic species such as fecal coliform and Ascaris eggs, but it is necessary to take further appropriate post-disinfection process to guarantee the effluent safety. However, fecal coliform and helminthes ova in our study are in compliance with the Egyptian Code for Wastewater Reuse in Restricted Irrigation (Fecal coliform $=1000$ and Helminthes ova $=1$ ). 


\section{Economic analysis}

To calculate the economic analysis of the proposed treatment system, a simulation of up-scaling module was designed for $500 \mathrm{~m}^{3} / \mathrm{d}$ using the integrated anaerobic wastewater treatment plant (5000 P.E.) with low strength wastewater (average $320 \mathrm{mgO}_{2} / \mathrm{l} \mathrm{COD)}$ ). The designed sizing was done based on the results of optimum total HRT of $6 \mathrm{hrs}$ and required removal efficiencies stated in the Egyptian Code for wastewater reuse in restricted irrigation $\left(\mathrm{COD}=80 \mathrm{mgO}_{2} / \mathrm{l}\right.$, $\mathrm{BOD}=40 \mathrm{mgO}_{2} / 1$ and $\left.\mathrm{TSS}=20 \mathrm{mg} / \mathrm{l}\right)$. The investment cost was calculated according to the current construction market in Egypt. The investment cost of the plant was about $\$ 112,000$, including land (\$0.1 million). The Per Capita investment cost is $\$ 20$. The annual operation costs are about $\$ 0.45$ per capita $\left(\$ 0.012 / \mathrm{m}^{3}\right)$. It is obvious that the investment cost of such integrated system is reduced by $40 \%$ from the conventional activated sludge process.

\subsection{Economic benefits of bio-gas utilization}

Produced methane gas $=19200 \mathrm{~L} / \mathrm{d}\left(19.2 \mathrm{~m}^{3} / \mathrm{d}\right)$

Equivalent produced energy $=213.12 \mathrm{KWh} / \mathrm{d}$

Energy demand for UASB reactor

Equation (3) is according to [19].

$$
=0.08 \mathrm{KWh} / \mathrm{kgCOD} \text { removed }=12.8 \mathrm{KWh} / \mathrm{d}
$$

Rest of energy $=150.32 \mathrm{KWh} / \mathrm{d}$;

This energy may be stored or discharged to the public network. The annual pay-back gained from the produced energy is $\$ 1500$ ( $\$ 0.30$ per Capita). This will reduce the annual cost of operation to only $\$ 0.15$ per capita, which considered a very cost effective module of operation of such plants. Based on the cost benefit analysis, it is obvious that the integrated anaerobic treatment system proved to be very cost effective compared to the conventional aerobic treatment process.

\section{Conclusion}

- The results of this study showed that low strength wastewater can be effectively treated using integrated anaerobic treatment unit consisting of three successive compartments mainly; primary sedimentation, packed bed anaerobic sludge blanket and inclined plate settler operated at low HRT for P-UASB of $4 \mathrm{hrs}$ with an average OLR of $2.6 \mathrm{COD} / \mathrm{m}^{3} /$ day. The quality of treated effluent in terms of COD, BOD and TSS removal rate were $78 \%$, $79 \%$ and $91 \%$, respectively.

- Results indicated that there is no need for primary sedimentation in case of treating low strength wastewater.

- The treatment unit removed considerably the pathogenic species as represented by fecal coliform and helminthes ova. 
- The integrated system proved to be very cost effective compared with conventional aerobic wastewater treatment system.

\section{References}

[1] Alvarez, J.A., Ruiz, I. \& Soto, M., Anaerobic digesters as a pretreatment for constructed wetlands, Ecological Engineering, 33, pp. 54-67, 2008.

[2] Anh, N.V., Ha, T.D., Nhue, T.H., Heiness, U., Morel, A., Moura, M. \& Schertenleib, R., Decentralized wastewater treatment - new concept and technologies for Vietnamese conditions, $5^{\text {th }}$ specialized conference on small water and wastewater treatment systems, Istanbul-Turkey, pp. 75-84, 2002.

[3] Lew, B., Taree, S., Beliavski, M., Dosoretz, C. \& Green, M., Anaerobic membrane bioreactor (AnMBR) for domestic wastewater treatment, Desalination, 243, pp. 251-257, 2009.

[4] Feng, H., Hu, L., Mahmood, Q., Qiu, C., Fang, C. \& Shen, D., Anaerobic domestic wastewater treatment with bamboo carrier anaerobic baffled reactor, International Biodeterioration \& Biodegradation, 62, pp. 232-238, 2008.

[5] Manariotis \& Grigoropoulos, Low-strength wastewater treatment using an anaerobic baffled reactor, Water Environmental Research, 74 (2), pp. 170 176, 2002.

[6] Sabrey, T., Evaluation of decentralized treatment of sewage employing upflow septic tank/ baffled reactor (USBR) in developing countries, Journal of Hazardous Materials, 174, pp. 500-505, 2010.

[7] Gopala Krishna, G.V.T., Kumar, P. \& Kumar, P, Treatment of low strength complex wastewater using an anaerobic baffled reactor (ABR), Biosource Technology, 99, pp. 8193-8200, 2008.

[8] Singh, S.P. \& Prerna, P., Review of recent advances in anaerobic packedbed biogas reactors, Renewable and Sustainable Energy Reviews, 13, pp. 1569-1575, 2009.

[9] Picanco, A.P., Vallero, M.V.G., Gianotti, E.P., Zaiat, M. \& Blundi C.E, Influence of porosity and composition of supports on the methanogenic biofilm characteristics developed in a fixed bed anaerobic reactor, Water Science Technology, 44, pp. 197-204, 2001.

[10] Cohen, Y., Biofiltration-the treatment of fluids by microorganisms immobilized into the filter bedding material: a review, Biosource Technology, 77, pp. 257-74, 2001.

[11] APHA, Standard Methods for the Examination of Water and Wastewater. $22^{\text {th }}$ ed., American Public Health Association, Washington, DC, USA, 2005.

[12] Metcalf \& Eddy, Wastewater engineering treatment, disposal and reuse. $4^{\text {th }}$ ed., McGraw-Hill, New York, 2005.

[13] Ghaniyari-Benis, S., Borja, R., Ali Monemian, S. \& Goodarzi, V., Anaerobic treatment of synthetic medium-strength wastewater using a multistage biofilm reactor, Biosource Technology, 100, pp. 1740-1745, 2009. 
[14] El mitwalli, T.A., Sklyar, V., Zeeman, G. \& Lettinga, G., Low temperature pre-treatment of domestic sewage in an anaerobic hybrid or an anaerobic filter reactor, Biosource Technology, 82, pp.233-239, 2002.

[15] Aquino, S.F. \& Stuckey, D.C., Characterization of soluble microbial products (SMP) in effluents from anaerobic reactors, Proc. $9^{\text {th }}$ Int. Symp. on Anaerobic Digestion, Antwerpen, Belgium, pp. 109-116, 2001.

[16] Baloch, M.I. \& Akunna, J.C, Granular bed baffled reactor (Grabbr): solution to a two-phase anaerobic digestion system, Journal of Environmental Engineering, 129 (11), pp. 1015-1021, 2003.

[17] Tawfik, A., Ohashi., A. \& Harada, H., Sewage treatment in a combined upflow anaerobic sludge blanket (UASB)-down-flow hanging sponge (DHS) system, Biochemical Engineering Journal, 29, pp. 210-219, 2006.

[18] Kobayashi, H.A., Stenstrom, M.K. \& Mah, R.A., Treatment of low strength wastewater using the anaerobic filter, Water Research, 17(18), pp. 903-909, 1982.

[19] Technologien, N., Bau- und Wirtschaftsberatung (TBW) GmbH, Frankfurt (Editor), Decentralized wastewater treatment methods for developing countries, GTZ - GATE, 2001. 